\title{
Dr. Anna Bayerova: Female Pioneer of Medicine in Bosnia and Herzegovina $^{1}$
}

\author{
Omer Ć. Ibrahimagić \\ Department of Neurology, University Cinical Center \\ Tuzla and School of Medicine, University of Tuzla, \\ 75000 Tuzla, Bosnia and Herzegovina \\ Correspondence: \\ omeribrahimagic@yahoo.com \\ Tel.: + 38735255341 ; + 38761670167
}

Received: 1 December 2019; Accepted: 15 December 2019

Dear Dr. Tahirović,

I read the article written by Fuchs and Tahirović in the first issue of Acta Medica Academica in 2019 with great attention (1). This excellent article about the history of medicine evaluates the life and enormous, but brief work of Dr. Anna Bayerova in Tuzla, Sarajevo, and Bosnia and Herzegovina.

The interesting fact is that for a quite long time it was not known precisely who was the first to start working in Tuzla and Bosnia and Herzegovina - a Czech or Polish female doctor? A few written documents show that Polish doctors were the first to start. According to Azabagić and Prašek-Calczynska, they were Dr. Teodora Krajewska and Dr. Jadwiga Olszewska $(2,3)$. According to Karahasanović, there was no female doctor in Bosnia and Herzegovina before Dr. Krajewska arrived in Tuzla (4). Dr. Anna Bayerova's time in Bosnia and Herzegovina was slightly longer than a year. This is probably the prime reason why she is not known so well.

In contrast, Fuchs and Tahirović, as well as Nečas, state that Anna Bayerova was in fact the first female doctor in Bosnia and Herzegovina $(1,5)$. According to Nečas, she was born in Vojtjehovo, near Prague, so perhaps not in Melnik. She ended her medical education due to her unfavorable material situation. Finally, she received her diploma after submitting her dissertation entitled: "Uber die Zahlenverhaltnisse der rothen und weissen Zellen im Blute vom Neugeborenen und Sauglingen" (About the ratio of red and white cells in the blood of newborns and infants) (5).

After careful analysis of the historical documents, it is clear that Teodora Krajewska was not the first official female doctor in Bosnia and Herzegovina. Without any doubt, Dr. Anna Bayerova was the female pioneer of medicine in Bosnia and Herzegovina. Furthermore, Dr. Bayerova had to promise not to get involved in any sort of political work in Bosnia and Herzegovina (6). Her medical work was not solely based in Tuzla, in fact, it was in Brčko, Gračanica and Derventa (7). Her success was even a surprise to the finance minister, Benjamin Kallay. After Dr. Bayerova heard that her work had been spoken of positively, she

\footnotetext{
${ }^{1}$ Comment on Article: Dr. Anna Bayerova: The First Official Female Doctor in Bosnia and Herzegovina.
} 
wrote: "The news that the administrators in Vienna are satisfied by my work caught my attention - I can't say I was ecstatic. I am so pleased by the grateful looks of my Muslim women and by their pleasure at being treated fairly and honestly, to the point where I lose interest in everything else" (8).

Key Words: Anna Bayerova - Tuzla - Bosnia and Herzegovina.

Conflict of Interest: The author declares that he has no conflict of interest.

\section{References}

1. Fuchs B, Tahirović H. Dr. Anna Bayerova: The First Official Female Doctor in Bosnia and Herzegovina. Acta Med Acad. 2019;48(1):121-6. DOI:105644/ama2006-124.249.
2. Azabagić S. One hundred years of health service in Tuzla [in Bosnian]. Acta Med Sal. 1974;3(2):520.

3. Prašek - Calczynska B. MD Teodora Krajewska - The first official female doctor in Bosnia [in Croatian]. In: Memoari jedne liječnice. Zagreb: Durieux; 1997. p. 103-16.

4. Karahasanović A. Tuzla hospital and its first doctors [in Serbian]. Srp Arh Celok Lek. 1958;10:1-5.

5. Nečas C. Work of official female doctors in Bosnia and Herzegovina 1892-1918 [in Bosnian]. In: Istorijski zbornik. Banjaluka: Institut za istoriju. 1988;9:91-110.

6. Anonymous. The first official state female doctor in Europe [in Czech]. Ženske listy. 1892;20:35-6.

7. Ibrahimagić OĆ, Zukić S, Čustović A. Health care in Tuzla and Tuzla area in the second half of the nineteenth century [in Bosnian]. Acta Med Sal. 2009;38(1):1-5.

8. Honzakova A. MD Anna Bayerova 1853-1924: The first Czech female doctor in Switzerland [in Czech]. Prague: Ženska narodni rada; 1937. p. 25. 